\title{
PENGARUH MODEL COOPERATIVE LEARNING TERHADAP KREATIVITAS BELAJAR MAHASISWA PENDIDIKAN SEJARAH IKIP PGRI PONTIANAK
}

\author{
Sahid Hidayat ${ }^{1}$, Agus Dediansyah $^{2}$ \\ ${ }^{1,2}$ Program Studi Pendidikan Sejarah \\ Fakultas Ilmu Pendidikan dan Pengetahuan Sosial IKIP PGRI Pontianak \\ Jalan Ampera Nomor 88 Pontianak - 78116, Telepon (0561) 748219 Fax. (0561) 589855 \\ Alamat e-mail: ${ }^{1}$ kelyk.hidayat@gmail.com
}

\begin{abstract}
Abstrak
Tujuan dalam penelitian ini adalah untuk mengetahui Pengaruh model cooperative learning terhadap kreativitas belajar mahasiswa Program Studi Pendidikan Sejarah di Institut Keguruan dan Iilmu Pendidikan (IKIP) PGRI Pontianak. Metode yang digunakan dalam penelitian ini adalah metode kuantitatif dengan pendekatan eksperimen. Teknik analisis data yang digunakan adalah teknik analisis data dan uji-t One sample test. Hasil penelitian menunjukkan bahwa terdapat pengaruh positif dan signifikan kreativitas belajar mahasiswa sebelum dan sesudah diterapkan model cooperative learning. Hal ini ditunjukkan dari besarnya nilai Sig. (2-tailed) lebih rendah dari nilai signifikasi $(0,000<0,05)$ dan nilai signifikansi sebesar 0,05 , yang berarti kurang dari $0,05(0,000<0,05)$.
\end{abstract}

Kata Kunci: cooperative learning; kreativitas belajar mahasiswa; IKIP PGRI Pontianak;

\begin{abstract}
The purpose of this study was to determine the effect of cooperative learning models on learning creativity of Program Studi Pendidikan Sejarah IKIP PGRI Pontianak students. The method used in this study is a quantitative method with an experimental approach. The data analysis technique used is the data analysis technique and the One sample test t-test. The results showed that there was a positive and significant influence of students 'learning creativity before and after the cooperative learning model was applied to students. This is indicated by the value of Sig. (2-tailed) is lower than the significance value $(0,000<0.05)$ and the significance value is 0.05 , which means less than $0.05(0,000<0.05)$.
\end{abstract}

Keywords: cooperative learning; students learning creativity; IKIP PGRI Pontianak

\section{PENDAHULUAN}

Pendidikan memiliki peran vital dalam membangun kemajuan suatu negara, tidak heran apabila banyak negara yang memberikan perhatian besar dalam dunia pendidikannya bisa menjadi negara berpengaruh di dunia dalam bidang teknologi, ekonomi, politik dan bidang lainnya. Sedangkan negara yang masih belum sepenuhnya memperhatikan dunia pendidikan memiliki tingkat perkembangan yang cukup lamban untuk menyaingi negara-negara maju. Oleh sebab itu, Indonesia dengan segala sumber dan potensi yang ada seharusnya 
memberikan perhatian penuh dalam dunia pendidikan agar mampu mengimbangi negara-negara lain. Namun saat ini patutlah kiranya kita memberikan apresiasi kepada pemerintah yang secara bertahap memberikan perhatian tersebut. Semoga ini adalah sinyal positif akan kemajuan dunia pendidikan.

Pemerintah tidak henti-hentinya memperbaiki sistem pendidikan nasional, lihat saja bagaimana pemerintah harus memutar otak dalam memenuhi tuntutan zaman seiring dengan arus perkembangan globalisasi yang begitu cepat untuk terus melakukan perubahan. Terlepas dari apakah perubahan yang dibuat sarat akan kepentingan politis atau tidak. Perbaikan-perbaikan yang dilakukan oleh pemerintah Indonesia bukan hanya baru-baru ini saja dilakukan, tapi semenjak pasca kemerdekaan pendidikan nasional tidaklah statis, pendidikan nasional selalu dinamis.

Terlepas dari kontroversi mengenai perubahan-perubahan kurikulum termasuk kurikulum 2013 ini, tentulah sudah seharusnya kita menyepakati perubahan-perubahan kurikulum yang terjadi pada kurikulum pendidikan nasional adalah keniscayaan, bahkan perubahan itu sebuah keharusan apabila terjadi perubahan dan perkembangan ilmu pengetahuan dan teknologi serta perubahan pola dan tuntutan kehidupan masyarakat (Zainuddin, 2008:234), dan jika kita tidak ingin terjebak dalam stagnasi, semangat perubahan perlu terus dilakukan (Hidayat, 2013:111).

Seiring dengan perubahan kurikulum, yang paling penting dalam hal ini adalah faktor guru. Sebab secanggih apapun suatu kurikulum dan sehebat apapun sistem pendidikan, tanpa kualitas guru yang baik, maka semua itu tidak akan membuahkan hasil yang maksimal. Guru diharapkan memiliki kemampuan dalam pengelolaan kegiatan belajar mengajar yang diperlukan untuk melaksanakan tugas dan fungsinya secara efektif dan efisien. Bila kemampuan ini tidak ada pada diri seorang guru, maka ia tidak akan berkompeten dalam melakukan tugasnya dan hasilnya pun tidak akan optimal.

Oleh karena itu, tugas seorang guru adalah menciptakan suasana belajar yang menyenangkan dan mampu menarik kreativitas siswa dalam belajar serta meningkatkan hasil belajar siswa pada pelajaran. Guru membutuhkan suatu 
strategi baru sehingga dapat merubah anggapan buruk siswa tentang sulitnya memahami materi yang ada pada mata pelajaran dan dapat meningkatkan semangat siswa dalam belajar. Strategi yang baik apabila diterapkan dalam pelaksanaan pembelajaran membuat siswa menjadi aktif dalam belajar dan berdiskusi, berani menyampaikan gagasan dan mampu menerima gagasan dari orang lain serta memiliki kepercayaan diri yang tinggi sesuai dengan pengembangan pendidikan karekter siswa di sekolah.

Berbicara mengenai pendidikan karakter siswa, salah satu dari nilai-nilai pendidikan karakter siswa adalah kreatif. Menurut Salahudin (2013:111) mengatakan "Kreatif adalah berfikir dan melakukan sesuatu untuk menghasilkan cara atau hasil baru dari sesuau yang telah dimiliki”. Menurut Satiadarma (2003:109) mengungkapkan bahwa kreativitas belajar merupakan salah satu modal yang harus dimiliki mahasiswa untuk mencapai prestasi belajar. Kreativitas mahasiswa tidak seharusnya diartikan sebagai kemampuan menciptakan sesuatu yang benar-benar baru, akan tetapi kecerdasan yang dimiliki mahasiswa dalam memandang ketentuan dimana masih perlu adanya bimbingan, pemahaman. Selain itu menurut Munandar (2012:25) bahwa kreativitas belajar sebagai kemampuan untuk menciptakan sesuatu yang baru, sebagai kemampuan untuk memberi gagasan baru yang dapat diterapkan dalam pemecahan masalah, atau sebagai kemampuan untuk melihat hubungan baru antara unsur yang sudah ada sebelumnya. Kreativitas seseorang dapat dilihat dari tingkah laku atau kegiatannya yang kreatif. Menurut Moreno (dalam Slameto, 2010: 146) bahwa yang penting dalam kreativitas bukanlah penemuan sesuatu yang belum pernah diketahui orang sebelumnya, melainkan bahwa produk kreativitas merupakan sesuatu yang baru bagi diri sendiri dan tidak harus merupakan sesuatu yang baru bagi orang lain atau dunia pada umumnya, misalnya seorang mahasiswa menciptakan untuk dirinya sendiri suatu hubungan baru dengan mahasiswa atau orang lain.

Berdasarkan pengertian dan pendapat yang telah dikemukakan tersebut dapat disimpulkan bahwa kreativitas belajar Sejarah adalah kemampuan untuk menemukan sesuatu yang baru, yang berpijak pada peristiwa masa lampau dan 
diperoleh melalui proses belajar dalam ranah koqnitif. Mahasiswa yang kreatif adalah mahasiswa yang mampu dalam menciptakan berbagai kreasi-kreasi dalam belajar.

Metode Pembelajaran yang kurang melibatkan peserta didik, akan mengakibatkan menurunnya keinginan dalam proses pembelajaran peserta didik, sehingga kreativitas belajarnya akan menurun dan pada akhirnya prestasi belajar juga tidak akan mendapatkan hasil yang optimal. Maka metode pembelajaran yang digunakan pada proses belajar dan mengajar sangat berpengaruh terhadap keberhasilan dalam prestasi belajar peserta didik.

Salah satu faktor yang dapat mempengaruhi kreativitas belajar dan prestasi belajar siswa yaitu dengan pemilihan model pembelajaran oleh guru. menurut Isjoni (2007:14) mengatakan cooperative learning adalah salah satu bentuk pembelajaran yang berdasarkan faham konstruktivisme. Menurut Suprijono, (2010:54) "Model pembelajaran cooperative adalah konsep yang lebih luas meliputi semua jenis kerja kelompok termasuk bentuk-bentuk yang dipimpin oleh guru atau diarahkan oleh guru".

Pembelajaran cooperative merupakan strategi belajar dengan sejumlah siswa sebagai anggota kelompok kecil yang tingkat kemampuannya berbeda. Dalam penyelesaian tugas kelompoknya, setiap siswa harus saling bekerja sama, saling membantu untuk memahami materi pelajaran. Dalam belajar dikatakan belum tuntas jika salah satu anggota belum menguasai bahan pelajaran. Cooperative mengandung pengertian bekerja bersama dalam mencapai tujuan bersama (Hasan, 1996:64). Dalam kegiatan cooperative, siswa dalam individual mencari hasil bagi seluruh anggota kelompoknya. Jadi belajar cooperative adalah pemanfaatan kelompok kecil dalam pengajaran yang memungkinkan siswa bekerjasama untuk memaksimalkan belajar mereka dan anggota lainnya dalam kelompok tersebut.

Model pembelajaran merupakan bagian dari strategi instruksional, model pembelajaran berfungsi sebagai cara untuk menyajikan, menguraikan, memberi contoh, dan memberi latihan kepada siswa untuk mencapai tujuan tertentu. Dalam proses belajar mengajar guru diharapkan untuk memilih model-model dari sekian 
banyak model yang telah ditemui oleh para ahli sebelum ia menyampaikan materi pengajaran untuk mencapai tujuan pembelajaran. Keberhasilan proses pembelajaran tidak lepas dari kemampuan guru mengembangkan model-model pembelajaran dengan tujuan untuk menciptakan kondisi pembelajaran yang memungkinkan siswa belajar secara aktif sehingga meraih hasil belajar dan prestasi yang optimal.

Institut Keguruan dan Ilmu Pendidikan (IKIP) PGRI Pontianak merupakan salah satu perguruan tinggi swasta yang menyelenggarakan pendidikan dalam bidang pendidikan program strata 1 (S1) sejarah. Selama dalam proses pembelajaran, pendidik selalu menerapkan metode diskusi, maupun ceramah dengan menggunakan media power point. Dalam penelitian ini, peneliti mencoba dalam proses perkuliahan menerapkan model pembelajaran cooperative learning yang berfariasi, selain untuk melihat pengaruh terhadap kreativitas belajar diharapkan sebagai bekal mahasiswa ketika sudah menyelesaikan program S1. Untuk itu peneliti ingin meneliti bagaimana penerapan model cooperative learning berpengaruh terhadap Kreativitas belajar mahasiswa di Institut Keguruan dan Iilmu Pendidikan (IKIP) PGRI Pontianak.

\section{METODE}

Penelitian ini merupakan penelitian eksperimen dengan variabel bebasnya yaitu model cooperive learning sedangkan variabel terikatnya yaitu aktivitas belajar. Bentuk penelitian yang digunakan adalah Pre-eksperimental design. Digunakannya bentuk pre-eksperimental design yang bertujuan untuk mengetahui pengaruh antara vaiabel bebas (model cooperative learning) dengan variabel terikat (aktivitas belajar).

Hadari Nawawi (2007:150) menyatakan bahwa: "Populasi adalah keseluruhan objek penelitian yang yang dapat dari manusia, bendabenda,hewan, tumbuh-tumbuhan, gejala-gejala, nilaitis atau peristiwa sebagai sumber data yang memiliki kareteristik tertentu dalam penelitian”. Adapun populasi dalam penelitian ini adalah seluruh mahasiswa program studi 
pendidikan sejarah semester IV tahun ajaran 2017/2018 pada mata kuliah sejarah intelektual yang terdaftar di sisfo IKIP PGRI pontianak yang berjumlah 56 mahasiswa. Langkah selanjutnya adalah menetapkan sampel penelitian. Sampel adalah bagian dari jumlah dan karakteristik yang dimiliki oleh populasi tersebut (Sugiyono,2013:118). Dan Arikunto, S (2010:174) menyatakan "sampel adalah sebagian atau wakil populasi yang diteliti". Sampel dalam penelitian ini digunakan seluruh mahasiswa kelas B Pagi semester IV mata kuliah sejarah intelektual yang berjumlah 32 mahasiswa.

Teknik pengumpulan data dalam penelitian ini adalah teknik komunikasi tidak langsung, sedangkan alat pengumpul datanya adalah angket. Penelitian yang diteliti merupakan suatu penelitian kuantitatif, sehingga dalam menganalisis data dilakukan dengan menggunakan rumus statistik. Rumus analisis statistik data yang pertama menggunakan rumus rata-rata atau mean, kemudian langkah selanjudnya untuk mencari mencari uji t one sample test.

\section{HASIL DAN PEMBAHASAN}

Data hasil angket mahasiswa sebelum menggunakan model pembelajaran cooperative Learning

Hasil dari analisis penelitian mengenai skor angket mahasiswa dengan menggunakan model pembelajaran Cooperative diketahui bahwa $\mathrm{n}=27$, skor tertinggi $=116$ dan skor terendah $=81$. Berdasarkan perhitungan statistik dasar yang dibantu dengan program SPSS versi 19 diperoleh Mean $=97,89$, Median = 97,00, Modus $=101$, Sandar Deviasi $=9,3$, dan varian $=86,18$. terdiri dari 8 kelas yaitu:

Tabel 1. Distribusi Frekuensi hasil angket mahasiswa sebelum menggunakan Model Cooperative Learning

\begin{tabular}{llr} 
& \multicolumn{3}{c}{ Statistics } \\
\hline Pretest & & \\
\hline N & Valid & 27 \\
\cline { 2 - 3 } & Missing & 0 \\
\hline Mean & & 97.89
\end{tabular}


Median

97.00

Mode

101

Std. Deviation

9.283

Variance

86.179

Minimum 81

\begin{tabular}{lr} 
Maximum & 116 \\
\hline
\end{tabular}

Sum

2643

Hasil distribusi frekuensi skor angket dengan menggunakan model Cooperative dapat dilihat pada grafik histogram pada Gambar 1 sebagai berikut:

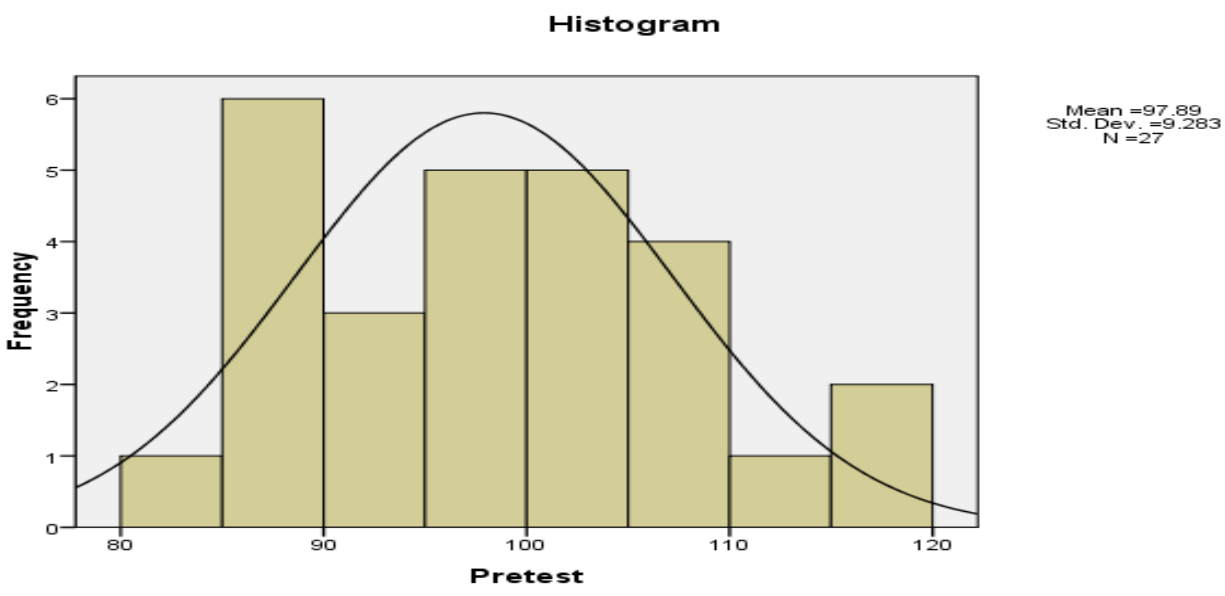

\section{Gambar 1. Histogram angket mahasiswa sebelum menggunakan Model Cooperative Learning}

Berdasarkan distribusi frekuensi di atas, maka mahasiswa dapat dikatakan bahwa angket mahasiswa sebelum diajarkan dengan model pembelajaran Cooperative cukup baik.

\section{Deskripsi Data hasil angket mahasiswa setelah diterapkan model pembelajaran Cooperative Learning}

Hasil dari analisis penelitian mengenai skor prestasi belajar mahasiswa dengan menggunakan model cooperaive dapat diketahui jumlah responden $(n)=$ 27 mahasiswa, nilai tertinggi $($ Maksimum $)=120$, skor terendah $($ minimum $)=80$, 
skor rata-rata $($ mean $)=104,15$; modus $($ mode $)$ sebesar 103 ; median sebesar 104,00; varians sebesar 71,593 dan simpangan baku (standar deviasi) = 8,461 adapun hasil perhitungan angket menggunakan aplikasi spss yaitu:

Tabel 2. Distribusi Frekuensi hasil angket postest mahasiswa

\begin{tabular}{lrr} 
& \multicolumn{1}{c}{ Statistics } \\
\hline Postest & & 27 \\
\hline & Valid & 0 \\
\cline { 2 - 3 } & Missing & 104.15 \\
\hline Mean & & 104.00 \\
\hline Median & $103^{\text {a }}$ \\
\hline Mode & 8.461 \\
\hline Std. Deviation & & 71.593 \\
\hline Variance & 80 \\
\hline Minimum & 120 \\
\hline Maximum & 2812 \\
\hline Sum &
\end{tabular}

a. Multiple modes exist. The smallest value is shown

Hasil distribusi frekuensi skor angket mahasiswa dengan menggunakan model cooperative dapat dilihat pada grafik histogram pada Gambar 2 sebagai berikut:

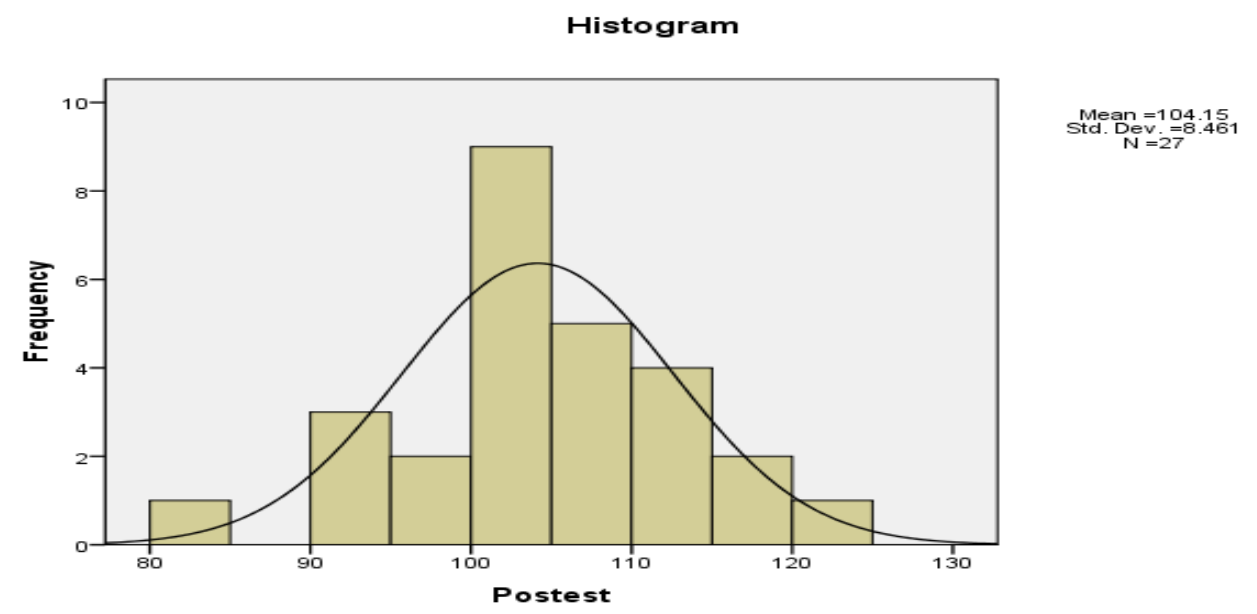

Gambar 2. Histogram hasil angket postest yang diajarkan dengan model cooperative 
Berdasarkan distribusi frekuensi di atas, dapat dikatakan bahwa hasil angket mahasiswa yang diajarkan dengan model cooperatif learning sudah baik.

Langkah selanjutnya dalam penelitian ini adalah menentukan nilai normalitas dan homogenitas. Uji normalitas dalam penelitian ini dilakukan untuk mengetahui apakah semua variabel penelitian berdistribusi normal atau tidak. Normalitas diujikan pada masing-masing variabel penelitian yang meliputi: aktivitas belajar mahasiswa sebelum diterapkan model cooperative learning dan aktivitas belajar mahasiswa setelah diterapkan model cooperative learning. Pengujian normalitas menggunakan teknik analisis liliefors dan untuk perhitungannya menggunakan program SPSS 16.0 for Windows. Hasil normalitas dalam penelitian disajikan berikut ini:

\section{Uji normalitas kreativitas mahasiswa sebelum menggunakan model pembelajaran Cooperative Learning}

Hasil dari pengujian statistik metode liliefors dengan menggunakan program SPSS versi 19, data kreatifitas belajar sejarah mahasiswa sebelum menggunakan model pembelajaran cooperative learning diperoleh besaran statistik untuk $n=27$. Data suatu variabel dinyatakan berdistribusi normal apabila uji normalitas lebih besar dari $\alpha=0,05$, berdasarkan hasil perhitungan diperoleh nilai signifikansi sebesar 0.694. Dengan demikian Shapiro-Wilk $=0,694>\alpha=$ 0,05, Sehingga dapat disimpulkan bahwa data angket mahasiswa sebelum diterapkan dengan model pembelajaran cooperative berasal dari populasi yang berdistribusi normal. Data hasil analisis dan grafik kenormalan dapat dilihat pada tabel 3 dibawah ini.

Tabel 3. Uji Normalitas kreativitas mahasiswa sebelum menggunakan model pembelajaran cooperative learning

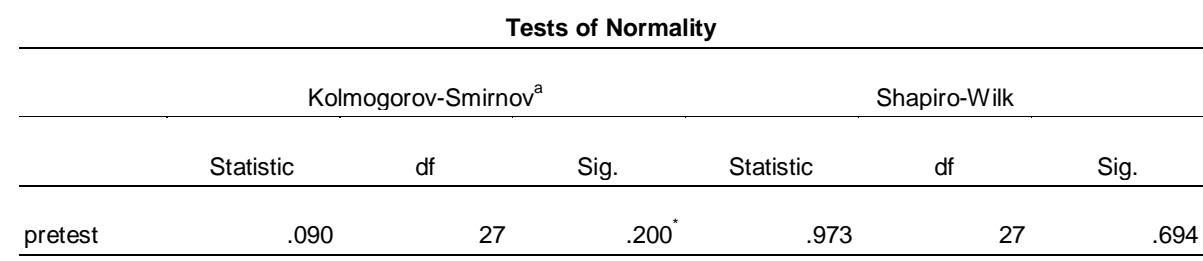

a. Lilliefors Significance Correction

*. This is a lower bound of the true significance. 


\section{Uji normalitas kreativitas mahasiswa setelah menggunakan model} pembelajaran Cooperative Learning

Hasil dari pengujian statistik metode liliefors dengan menggunakan program SPSS versi 19, data kreativitas belajar sejarah mahasiswa setelah menggunakan model cooperative Learning diperoleh besaran statistik untuk $\mathrm{n}=$ 27. Data suatu variabel dinyatakan berdistribusi normal apabila uji normalitas lebih besar dari $\alpha=0,05$, berdasarkan hasil perhitungan diperoleh nilai signifikansi sebesar 0.368. Dengan demikian Shapiro-Wilk $=0,368>\alpha=0,05$, Sehingga dapat disimpulkan bahwa data angket mahasiswa setelah diterapkan model cooperative learning berasal dari populasi yang berdistribusi normal. Data hasil analisis dan grafik kenormalan dapat dilihat pada tabel dibawah ini.

Tabel 4. Uji Normalitas kreativitas mahasiswa setelah menggunakan model pembelajaran cooperative learning

\begin{tabular}{|c|c|c|c|c|c|c|}
\hline \multicolumn{7}{|c|}{ Tests of Normality } \\
\hline & \multicolumn{3}{|c|}{ Kolmogorov-Smirnov ${ }^{a}$} & \multicolumn{3}{|c|}{ Shapiro-Wilk } \\
\hline & Statistic & df & Sig. & Statistic & df & Sig. \\
\hline postest & .141 & 27 & .183 & .960 & 27 & .368 \\
\hline
\end{tabular}

a. Lilliefors Significance Correction

Setelah mengetahui nilai normalitas data sebelum dan setelah di lakukan tindakan, maka langkah selanjutnya adalah menentukan nilai homogenitas. Tujuan dari dilakukannya uji homogenitas adalah untuk mengetahui apakah variansivariansi berasal dari populasi yang memiliki varian yang sama (homogen). Angket belajar mahasiswa akan dilakukan uji homogenitas dengan menggunakan uji Bartlet yang dihitung dengan bantuan SPSS 19. Hipotesis uji homogenitas dinyatakan homogen jika signifikansi yang diperoleh $>a$, maka variansi setiap sampel sama (homogen) sebaliknya jika signifikansi yang diperoleh $<a$, maka variansi setiap sampel tidak sama (tidak homogen).

Pengambilan keputusan dilakukan dengan angka probalitas dimana probalitas sig > 0,05 maka H0 diterima, sebaliknya apabila probalitas sig < 0,05 
maka H0 ditolak. Berdasarkan hasil perhitungan statistik diperoleh nilai signifikansi 0,290 dan nilainya lebih tinggi dari 0,05. Hal ini berarti H0 diterima atau populasi mempunyai variansi homogen. Adapun data hasil selengkapnya dapat dilihat dalam tabel dibawah ini.

Tabel 5. Uji Homogenitas

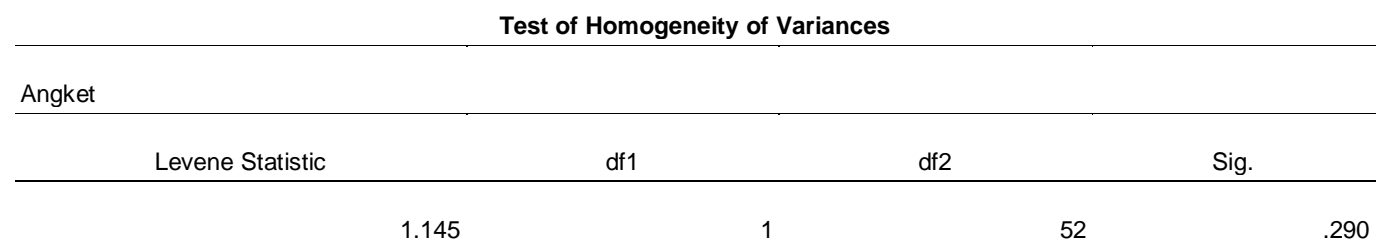

Langkah selanjutnya adalah pengujian hipotesis. Pengujian hipotesis dilakukan untuk mengetahui apakah hipotesis yang dirumuskan dapat teruji kebenarannya atau tidak terbukti. Maka Pengujian hipotesis dalam penelitian ini menggunakan tekniik analisis Paired T Test. Adapun output yang dihasilkan dapat terlihat pada tabel 4. berikut ini:

T-Test

Tabel 6. Uji T-Test

\begin{tabular}{cccccc}
\hline \multicolumn{5}{c}{ Paired Samples Statistics } \\
\hline \multirow{2}{*}{ Pair 1 } & Mean & $\mathrm{N}$ & Std. Deviation & Std. Error Mean \\
\hline & Sebelum & 97.89 & 27 & 9.283 & 1.787 \\
\cline { 2 - 6 } & Sesudah & 104.15 & 27 & 8.461 & 1.628 \\
\hline
\end{tabular}

Tabel 7. Uji paired sample correlations

\begin{tabular}{llllll}
\hline \multicolumn{7}{c}{ Paired Samples Correlations } \\
\hline & $\mathrm{N}$ & Correlation & Sig. \\
\hline Pair 1 & Sebelum \& Sesudah & & & & \\
\hline
\end{tabular}

Paired Samples Test

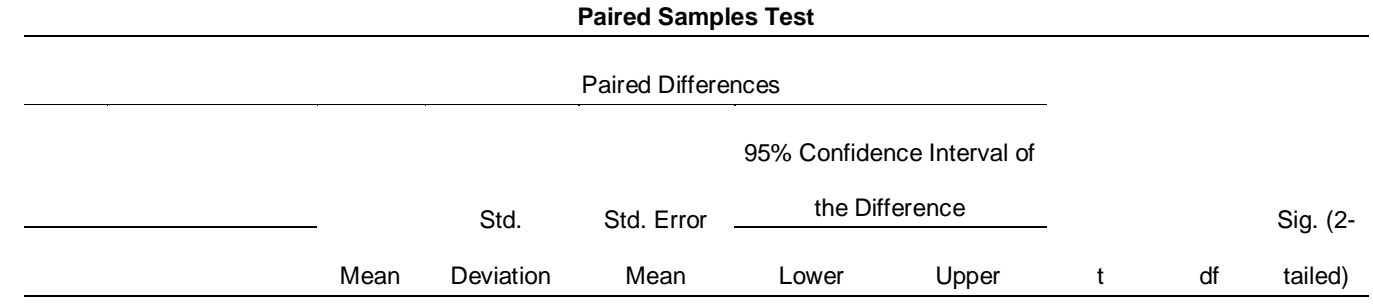




\begin{tabular}{|c|c|c|c|c|c|c|c|c|c|}
\hline \multicolumn{10}{|c|}{ Paired Samples Correlations } \\
\hline \multirow{2}{*}{ Pair 1} & \multirow[b]{2}{*}{$\begin{array}{l}\text { Sebelum - } \\
\text { Sesudah }\end{array}$} & \multirow[b]{2}{*}{-6.259} & \multirow[b]{2}{*}{7.654} & \multirow{2}{*}{$\begin{array}{l}\mathrm{N} \\
1.473\end{array}$} & \multirow{2}{*}{$\begin{array}{l}\text { Correlation } \\
-9.287\end{array}$} & \multicolumn{4}{|c|}{ Sig. } \\
\hline & & & & & & -3.231 & -4.249 & 26 & .000 \\
\hline
\end{tabular}

Menurut Priyatno (2010:89) jika angka signifikasi hasil riset $<0,05$, maka hubungan kedua variabel signifikan. Jika angka signifikasi hasil riset >0,05, maka hubungan kedua variabel tidak signifikan. Dari tabel di atas diperoleh taraf signifikan 0,000 ini menunjukan terdapat pengaruh model pembelajaran cooperatif pada mata kuliah sejarah intelektual terhadap kreativitas belajar mahasiswa di Kelas B semester IV program studi Pendidikan Sejarah.

Penerapan model cooperative merupakan salah satu alternatif yang dapat diterapkan kepada mahasiswa karena dapat meningkatkan kreativitas dan keaktifan mahasiswa di dalam kelas. Selain itu model cooperative ini dapat meningkatkan pemahaman belajar mahasiswa karena dalam proses pembelajaran, mahasiswa diberi kesempatan untuk berinteraksi dengan mahasiswa lain, suasana belajar dikelas dapat diciptakan sebagai suasana permainan, ada kompetisi antar mahasiswa dalam memecahkan masalah yang terkait dengan materi perkuliahan, serta adanya penghargaan sehingga mahasiswa dapat belajar dalam suasana yang menyenangkan.

Penerapan model Cooperative dalam proses pembelajaran sebenarnya sudah cukup menarik bagi mahasiswa, hanya saja dalam proses pembelajaran memerlukan pemahaman yang lebih mendalam sehingga membuat proses pembelajaran mengalami sedikit hambatan. Dalam kegiatan belajar mengajar juga sudah cukup aktif dan menyenangkan, hanya saja dalam penguasaan konsep dasar materi perkuliahan mengalami sedikit hambatan. Dari keterbatasan inilah mengakibatkan materi-materi pembelajaran yang diharapkan mampu dimengerti dan dipelajari oleh mahasiswa secara lebih jelas sehingga mengalami kendala. Keterbatasan lainnya adalah mahasiswa tidak menyiapkan materi atau belajar terlebih dahulu dirumah sehingga pada saat proses pembelajaran mahasiswa menjadi pasif dalam penerapan model Cooperative ini. 


\section{SIMPULAN}

Berdasarkan hasil penelitian dan pembahasan, maka dapat ditarik kesimpulan yakni, "Terdapat pengaruh positif dan signifikan kreativitas belajar mahasiswa sebelum dan sesudah diterapkan model cooperative learning pada mahasiswa semester IV tahun akademik 2017-2018 Program Studi Pendidikan Sejarah di Institut Keguruan dan Iilmu Pendidikan (IKIP) PGRI Pontianak. Hal ini ditunjukkan dari besarnya nilai Sig. (2-tailed) lebih rendah dari nilai signifikasi $(0,000<0,05)$ dan nilai signifikansi sebesar 0,05 , yang berarti kurang dari 0,05 $(0,000<0,05)$. Jadi dapat disimpulkan bahwa terdapat pengaruh antara kreatifitas belajar sebelum dan sesudah diterapkan model cooperative learning dalam proses pembelajaran.

\section{DAFTAR PUSTAKA}

Arikunto, S. 2010. Prosedur Penelitian Suatu Pendekatan Praktik. Jakarta: Rineka Cipta.

Hasan. 1996. Pendidikan Ilmu-Ilmu Sosial. Buku 1 dan 2. Bandung: Jurusan Sejarah FPIPS IKIP Bandung.

Hidayat, Sholeh. 2013. Pengembangan Kurikulum Baru. Bandung : PT Remaja Rosdakarya.

Isjoni. 2007. Cooperative learning. Bandung: Alfabeta.

Munandar, Utami. 2012. Pengembangan Kreativitas Anak Berbakat. Jakarta: Rineka Cipta.

Nawawi, H. 2007. Metode Penelitian di Bidang Sosial. Yogyakarta: Gajah Mada University Press.

Priyatno, Duwi. 2010. Teknik Mudah dan Cepat Melakukan Analisis Data Penelitian Dengan SPSS dan Tanya Jawab Ujian Pendadaran. Yogyakarta: Gaya Media.

Salahudin, Anas. dan Alkrienciehie, I. 2013. Pendidikan Karakter. Bandung: Pustaka Setia.

Satiadarma, Monty, P. \& Waruwu, Fidelis, E. 2003. Mendidik Kecerdasan. Jakarta : Pustaka Populer Obor.

Slameto. 2010. Belajar dan faktor-faktor yang mempengaruhinya. Jakarta: Rineka Cipta. 
SOSIAL HORIZON: Jurnal Pendidikan Sosial,

Vol. 6, No. 2, Desember 2019

Sugiyono. 2013. Metode Penelitian Pendidikan Pendekatan Kuantitatif, Kuaitatif dan $R \& D$. Bandung: Alfabeta.

Suprijono, Agus. 2010. Cooperative Learning Teori \& Aplikasi Paikem.

Yogyakarta: Pustaka Pelajar.

Zainuddin. 2008. Reformasi Pendidikan. Yogyakarta: Pustaka Pelajar. 